\title{
Power to Influence Leadership Perceptions and Innovatively Challenge the Status Quo: President Donald Trump and Social Activism
}

\author{
Mariana J. Lebrón, Ph.D. \\ Assistant Professor, Management \& Leadership \\ Towson University
}

\begin{abstract}
Daring to challenge the status quo impacts innovation. Yet, successful outcomes depend on individual risk-taking and choice to influence others to support new ideas. This Challenging the Status Quo exercise illustrates how leaders use power and influencing tactics to challenge norms by analyzing Donald Trump's journey as the $45^{\text {th }}$ U.S. President to defy experts and successfully influence followers to support his non-traditional candidacy: businessman lacking political experience becoming leader of the free world. Through integrating videoclips and polls, instructors make power visible, relevant, and thought-provoking as students apply power theory and influencing tactics perspectives to analyze (a) how leaders impact followers' perceptions, (b) students mutual-influencing strategies, (c) power's relationship with social identity and privilege, and (d) social impact on innovation via activism and free speech.
\end{abstract}

\section{Issue Statement}

The 2016 U.S. Presidential Race not only transformed how leaders successfully challenge the status quo, but also created innovative teaching opportunities in this new leadership era. Since successful leadership development programs teach students effective skills to communicate ideas, understand others' opinions, and influence decisions, how can we make classrooms psychologically-safe places for authentic student voices to assess how leaders influence them daily? As a political outsider winning the highest U.S. leadership position, President Trump inadvertently mobilized student activism, bringing political correctness and free speech questions into the open. Consequently, he and his challengers ignited activism as a form of innovation, "the capacity to generate ideas...that are novel and useful" (Chan, Fu, Schunn, Cagan, Wood, \& Kotvsky, 2011, p.1). Yet, successful innovation depends on understanding power and influence.

With company leaders' and students' activism increasing, learning how to challenge the status quo is critical in today's world, thus inspiring leadership educators to creatively make power lessons relevant to students' lives. After Matt Maloney, Grubhub CEO, publicly spoke against Trump's "nationalist, anti-immigrant, and hateful policies" and committed to fighting for employees' rights, Grubhub's stock dropped 4\% (Taranto, 2016). In 2017, individuals began resurrecting innovative methods for voicing new ideas challenging norms through increasing world protests about social justice, liberal, and conservative free speech issues. Inspired by one grandmother's call for a "Women's March on Washington", 2.6 million people participated in over 600 women's rights marches (Przybyla \& Schouten, 2017), motivating approximately 11,000 women to run for political offices (Kurtzleben, 2017). After University of California- 
Berkeley cancelled conservative speaker Ann Coulter's campus speech, Berkeley College Republicans sued for free speech violations (St. John, 2017).

By making course material relevant to students, leadership educators motivate student engagement in learning (Burke \& Moore, 2003). World leaders, such as Genghis Khan, George Washington, and Nelson Mandela, have shaped history and been effective examples in leadership education (e.g., Bongila, 2011). Similarly, critical moments surrounding this election provide leadership lessons relevant to college students not only because they can vote (Niemi \& Hanmer, 2010), but also because the election provides historic first examples in challenging the status quo. Despite their voting rights, less than half of 18 to 24 year-olds voted in previous elections: $41.9 \%$ in $2004,44.3 \%$ in $2008,38 \%$ in 2012 (File, 2014), and approximately $50 \%$ of 18 to 29 year-olds in 2016 (Tufts University, 2016).

By critically analyzing how power and influencing tactics are used in this exercise, students learn how leaders transform the status quo. Students consider President Trump, political candidates, and analysts using videoclips and polls related to three historic moments during which President Trump defied political expert opinion and gained public support demonstrating that a political outsider and businessman could win: (a) first 2015 Republican Primary Candidate Debate (Fox News, 2015) that transformed public perceptions (Diaz, 2015; Martin, 2016); (b) first U.S. Presidential Candidate debate, the first time a woman and political outsider debated as top two presidential candidates; and (c) President Trump's inaugural speech. Despite experts' arguments he lost the first Republican primary debate (Fox News, 2015), his presidential candidacy support increased. Further, Trump's inauguration speech legitimized not only that the status quo had changed, but more importantly, how to change it. Consequently, he ignited the social protest movement rise on all sides: Conservatives', Liberals', and individuals' free speech rights to challenge issues globally.

World leaders' speech, diplomacy, and decision-making skills set behavioral standards for discussing leadership effectiveness and ineffectiveness. This exercise's objectives include students learning: (a) to describe how different power sources and influencing tactics impact leadership perceptions, (b) to critically evaluate their use, (c) to practice conveying opinions and persuasion using influencing tactics, and (d) to become self-aware of how they are influenced. By creating classroom space to discuss a leader who is paradoxically both polarizing and empowering, instructors innovatively challenge the status quo, proactively role-modeling constructive leadership dialogue within classrooms.

\section{Literature Review}

Power, Leaders, and Influence in the U.S. Presidential Election. Power influences leadership perceptions (Koslowsky, Schwarzwald, \& Ashuri, 2001; Schwarzwald, Koslowsky, \& Agassi, 2001). Social power is the potential ability of an agent to influence targets to act as the agent wants (French \& Raven, 1959; Raven, 1992, 2008) by controlling resources the target values within their interdependent relationship (Galinsky, Rucker \& Magee, 2015; Magee \& Galinsky, 2008). Powerful leaders influence followers to act and/or change beliefs (Pierro, Raven, Amato, \& Bélanger, 2013; Raven, 1993) by providing or withholding valued resources (Keltner, Gruenfeld, \& Anderson, 2003). Extending power theory to this context, presidential 
candidates and voters exist in an interdependent relationship; candidates act as agents controlling resources voters value (e.g., social security, safety, education, taxes), while voters control votes candidates value.

Social power bases. Followers' decisions to act as the leader wants depends on the leader's power base (Pierro et al., 2013). Although later expanded by Raven (1992, 1993, 2008), six bases for social power (French \& Raven, 1959; Raven, 1965) are traditionally addressed in leadership courses: legitimate power based in formal authority position; expert power in specific content domain knowledge; reward power in controlling valued resources; coercive power in perceived punishments; referent in identifying with agent; and informational power in controlling information (Raven, 1992, 1999). Depending on the degree of force limiting the target's autonomy, these bases are harsh or soft (Pierro, Cicero, \& Raven, 2008; Pierro, Kruglanski, \& Raven, 2012; Raven, Schwarzwald, \& Koslowsky, 1998).

Influencing strategies. Leaders impact followers' perceptions by using legitimization, rational persuasion, ingratiation, inspirational appeals, exchange, and pressure influencing tactics to persuade them to change their beliefs or actions (Kipnis, Schmidt, Swaffin-Smith, \& Wilkinson, 1984; Kipnis, Schmidt, \& Wilkinson, 1980; Schriesheim \& Hinkin, 1990; Simpson, Farrel, Oriña, \& Rothman, 2014). Legitimization reinforces leader's decision-making authority. Rational persuasion uses logical arguments based on target's needs. Ingratiation uses complements. Inspirational appeals consider the target's values and goals. Exchange uses reciprocity and pressure builds on target's fear of losing valued rewards. People effectively influence others when using tactics based on the agent's needs and target's ability to produce outcomes (Kipnis et al., 1980).

Critical Thinking in Assessing Power "In the News". Critical thinking involves analyzing different perspectives to determine an individual's beliefs about issues. Media impact how organizational leaders interpret institutional pressures regarding government, organizations, and societal expectations in decision-making (Clegg, 1989; DiMaggio \& Powell, 1983; Hardy \& Clegg, 1996; Pfeffer, 1981). Many students are eligible voters and future organizational leaders. In examining societal issues, journalists present audiences with factual evidence and analysts' opinions regarding what these facts mean practically for those with decision-making power, thus influencing students' voting decisions. Discussing election media coverage provides an engaging context for students to critically analyze power and influencing strategies. Because no universally-accepted view of leadership effectiveness exists (Adler, 1997) and scholars define power differently (Sturm \& Antonakis, 2015), examining how political leaders use power to challenge the status quo in an election context allows students' intellectual freedom to share constructive opinions that challenge others'; no correct answer exists.

Presidential election debates and expert analyses demonstrate how powerful leaders use influencing tactics to manipulate information asymmetry conditions, information-sharing processes and decision-making effectiveness to influence perception (Diesing, 1962; Edmonson, Roberto \& Watkins, 2003). For example, after candidates presented their versions of factual evidence, Washington Post journalist Glen Kessler (2015) used rational persuasion tactics to argue 21 claims they made during the 2015 Republican Primary Debate were questionable. 
Debates: Power and Influence Teaching Tools. Debate exercises stimulate students' critical thinking skills regarding contemporary issues by considering multiple perspectives, such as debate simulations examining different stakeholder perspectives regarding social security (e.g., Goertzen, 2007). Presidential debates are useful for instructors both to demonstrate visually how power transforms traditional leadership perceptual norms and to access supplemental instructional media resources. Analysts' opinions and poll results are readily available for adding diverse insight. Remaining focused on one world leader's journey to influence public perceptions, instructors guide students in examining Trump's decisions to impact voter perceptions as presidential candidate, and then in mobilizing public support for his presidential vision.

Debates provide historical visual records for students to learn how elected leaders and their competitors challenged traditionally-accepted leadership norms, extending class dialogue about diversity. Although Hillary Clinton and Trump's Republican competitors lost, instructors can ask whether their losing efforts effectively challenged the status quo. For example, in appealing to Christian voters, Senator Ted Cruz was the first presidential candidate to launch a presidential campaign at "Liberty - the largest Christian university" (Draper, 2016). Carly Fiorina was the first woman to declare Republican presidential nomination candidacy (Mitchell, 2015) and Hillary Clinton was the first woman to win the Democratic presidential nomination. How do gendered communication (Lee \& Lim, 2016) and stereotypes influence leaders' attempts to challenge norms? Further, how can we evaluate sexism and misogyny critiques (e.g., Wilz, 2016)?

\section{The Exercise: Challenging the Status Quo}

This presidential election context motivates students to learn about power and influence not only because it changed traditional voting behavioral norms (Barrone, 2015; Bryant, 2016), but also because President Trump defied analysts' expectations and won (Burns \& Martin, 2016). In analyzing Trump's powerful rise, students discuss three critical moments during which he influenced public perceptions: (a) first 2015 Republican primary debate, (b) 2016 presidential debate with Clinton, and (c) inaugural speech. In optimizing time constraints, I found these situations motivated discussion because they illustrate his power and tendency to use inspirational appeals and personal appeals, rather than rational persuasion, influencing tactics to impact perception.

Part 1. Pre-Class Assignment. As a written assignment, students complete readings about power and influencing tactics (Table 1). Supplemental readings about social identity and privilege are suggested as examples for enriching discussions with gender-specific topics. 
Table 1.

Leadership Readings

\begin{tabular}{|c|c|}
\hline Type & Description \\
\hline Leadership Textbook & Power types and influencing tactics (Lussier \& Achua, 2013, p.149-155). \\
\hline $\begin{array}{l}\text { Social identity, } \\
\text { power and } \\
\text { influence } \\
\text { (suggested } \\
\text { supplemental } \\
\text { reading) }\end{array}$ & $\begin{array}{l}\text { Lean In: Women, Work, and the Will to Lead (Sandberg, 2013) } \\
\text { - Chapter 1. The Leadership Ambition Gap: What Would You Do } \\
\text { If You Weren't Afraid? } \\
\text { o Fear influences behavior. } \\
\text { - Chapter 2. Sit at the Table } \\
\text { O Self-defeating behavior. } \\
\text { - Chapter 3. Success and Likeability } \\
\text { o Navigating expected behavioral norms. } \\
\text { - Chapter 6. Seek and speak your truth. } \\
\text { o Communicating authentically. } \\
\text { - Chapter 10. Let's Start Talking About It } \\
\text { o Gender equality. }\end{array}$ \\
\hline
\end{tabular}

Students watch videoclips (Figure 1) illustrating leaders' influencing strategies (Figure 2), and develop arguments for (in)effective use of influencing tactics on perceptions (Figure 3 Worksheet).

\section{Challenging the Status Quo Assignment}

Using power and influence concepts, analyze how leaders impacted your perception of their leadership ability.

Answer these questions (1-2 pages):

1. How did candidates' words and actions influence your leadership potential perceptions? Specifically, state power sources and influencing tactics used.

2. Who impacted your perception most effectively and ineffectively?

Be prepared to discuss answers in class.

\section{Video Clips*:}

- 2015 Republican Primary - First round electability questions (http://video.foxnews.com/v/4406746003001/watch-a-replay-of-fox-news-prime-timepresidential-debate/?\#sp=show-clips $)(20 \mathrm{mins} ; 0: 00-22: 00)$

- 2016 Presidential Debate https://www.nytimes.com/video/us/politics/100000004673000/fullvideo-first-presidential-debate.html (90 mins)

- 2017 President Inauguration Speech(https://www.whitehouse.gov/inaugural-address) (17 mins; 28:23-45:11)

*Note: Copy and paste links to view videoclips.

Figure 1. Challenging the Status Quo Pre-Class Discussion Assignment 


\begin{tabular}{|c|c|c|c|}
\hline \multicolumn{2}{|c|}{ INFLUENCING TACTIC } & \multirow{2}{*}{$\begin{array}{r}\text { POWER } \\
\text { BASE } \\
\text { Legitimate }\end{array}$} & \multirow{2}{*}{$\begin{array}{l}\text { ANY RELEVANT VISIBLE DISPLAYS OF LEADERS } \\
\text { USING THESE INFLUENCING TACTICS? } \\
\text { Communicating formal authority to implement objectives }\end{array}$} \\
\hline LEGITIMIZATION & Formal authority & & \\
\hline CONSULTATION & $\begin{array}{l}\text { Participative management; seek others' } \\
\text { opinions about implementing a goal }\end{array}$ & Legitimate & $\begin{array}{l}\text { Communicating they want to know followers' opinions } \\
\text { about their ideas }\end{array}$ \\
\hline $\begin{array}{l}\text { RATIONAL } \\
\text { PERSUASION }\end{array}$ & $\begin{array}{l}\text { Logical arguments with factual evidence to } \\
\text { persuade others to support them based on } \\
\text { others' needs. }\end{array}$ & $\begin{array}{l}\text { Legitimate } \\
\text { Expert } \\
\text { Information }\end{array}$ & $\begin{array}{l}\text { Communicating logical argument for stated objectives by: } \\
\text { providing rationale for goal; explaining others' benefits; } \\
\text { providing evidence to achieve goal; describing plan for } \\
\text { potential problems; and, explaining how ideas are better } \\
\text { than others' (Lussier, 2013: 151) }\end{array}$ \\
\hline INGRATIATION & Friendly; praising others & Legitimate & Complimenting others \\
\hline $\begin{array}{l}\text { INSPIRATIONAL } \\
\text { APPEALS }\end{array}$ & Appeal to follower's values & $\begin{array}{l}\text { Referent } \\
\text { Information }\end{array}$ & $\begin{array}{l}\text { Displaying feelings in appealing to followers' emotions to } \\
\text { convey understanding their values, hopes, fears and goals }\end{array}$ \\
\hline $\begin{array}{l}\text { PERSONAL } \\
\text { APPEALS }\end{array}$ & Loyalty and friendship & Referent & Appealing to coalitions for support \\
\hline COALITION & $\begin{array}{l}\text { Using influential people to persuade others' } \\
\text { support }\end{array}$ & Connection & Conveying key relationships with powerful people \\
\hline EXCHANGE & Offer rewards for help & Reward & Communicating control of valued resources \\
\hline PRESSURE & $\begin{array}{l}\text { Build on others' fear of losing valued } \\
\text { resources }\end{array}$ & Coercive & Communicating negative consequences for not supporting \\
\hline
\end{tabular}

Based on Lussier \& Achua (2013, p. 149-156)

Figure 2.

Seeing is Believing: Power and Influencing Tactics Handout 


\begin{tabular}{|c|c|c|c|}
\hline EVENT & \multicolumn{2}{|c|}{ TOPIC -LEADERS (LOCATION) } & POWER BASE/INFLUENCING TACTICS \\
\hline \multirow{9}{*}{$\begin{array}{c}2015 \\
\text { FIRST } \\
\text { REPUBLICAN } \\
\text { PRIMARY } \\
\text { DEBATE }\end{array}$} & \multirow{9}{*}{ Electability } & $\begin{array}{l}\text { Dr. Ben Carson }(5: 59-7: 25) \\
\text { Foreign policy expertise }\end{array}$ & \\
\hline & & $\begin{array}{c}\text { Senator Marco Rubio (7:25-9:09) } \\
\text { Qualifications }\end{array}$ & \\
\hline & & $\begin{array}{c}\text { Governor Jeb Bush (9:09-10:31) } \\
\text { Family dynasty }\end{array}$ & \\
\hline & & $\begin{array}{l}\text { Donald Trump (10:33-12:43) } \\
\text { Comments about women }\end{array}$ & \\
\hline & & $\begin{array}{c}\text { Ted Cruz (12:45-14:12) } \\
\text { Divisiveness in minority outreach }\end{array}$ & \\
\hline & & $\begin{array}{c}\text { Governor Chris Christie (14:14-15:55) } \\
\text { Financial management }\end{array}$ & \\
\hline & & $\begin{array}{l}\text { Governor Walker (16:01-17:01) } \\
\text { Pro-life platform }\end{array}$ & \\
\hline & & $\begin{array}{l}\text { Governor Huckabee (17:03-18:39) } \\
\text { Abortion and same-sex marriage }\end{array}$ & \\
\hline & & $\begin{array}{l}\text { Governor Kasich (19:59-21:46) } \\
\text { Religion }\end{array}$ & \\
\hline $\begin{array}{c}2016 \\
\text { PRESIDENTIAL } \\
\text { DEBATE }\end{array}$ & \multicolumn{2}{|c|}{\begin{tabular}{|l} 
President Donald Trump and Hillary Clinton \\
- Prosperity: Jobs/taxes \\
- America's direction: Race \\
Security: ISIS; cybersecurity; nuclear threats
\end{tabular}} & \\
\hline $\begin{array}{l}2017 \text { PRESIDENT'S } \\
\text { INAUGURATION }\end{array}$ & \multicolumn{2}{|c|}{ President Trump's Inauguration Speech } & \\
\hline
\end{tabular}

\section{Figure 3.}

Analyzing Leaders' Power and Influence Worksheet 
Part 2. In-Class Facilitation. The in-class group discussion has 6 steps with estimated times for class of 27.

Step 1. (In)Effective Influencer? (Small Groups; 15 mins) Divide class into groups of 3-5 students and have them share answers about leaders' power and influencing effectiveness that were in videoclips. Using theoretical concepts, small groups develop two examples of effective and ineffective influencing tactic use. Groups record answers on whiteboards. By listening to others' arguments, they learn how individual perceptions about power and influence differ based on experiences. For example, students defined influencing effectively differently: "honest/ethical in answering questions"; "most persuasive in arguments, regardless of whether the facts are true"; and "walked their talk". Consequently, this exercise component is particularly engaging in small groups, who agree on (in)effective influence examples, but need to develop mutuallyagreed upon arguments explaining why.

Step 2. Class Discussion "How leaders influence follower perceptions" (Entire class; 25 mins). Each group presents their ideas, and answers questions. Illustrative examples including videoclip location are provided for instructors to stimulate dialogue: (a) first 2015 Republican Primary Debate (Table 2), (b) first 2016 Trump and Clinton debate (Table 3), and (c) inaugural speech (Table 4). The first round of the 2015 Republican Primary debate questions concerned electability. Candidates' qualifications are presented on-screen, and viewers can see and hear audience's responses. These clips illustrate candidates' influencing tactics with each other and anchors. 
Table 2.

Republican 2015 Presidential Primary Debate Influencing Tactics

\begin{tabular}{|c|c|c|c|c|}
\hline Topic & Who & Description & $\begin{array}{l}\text { Influencing Tactic } \\
\text { (location) }\end{array}$ & Illustrative Examples \\
\hline \multirow[t]{2}{*}{ Qualifications } & $\begin{array}{l}\text { Senator Marco } \\
\text { Rubio }\end{array}$ & Experience & $\begin{array}{l}\text { Rational persuasion, } \\
\text { coalition, inspirational } \\
\text { appeals }(7: 25-9: 09)\end{array}$ & $\begin{array}{c}\text { "How is Hillary Clinton gonna lecture me about living paycheck to } \\
\text { paycheck? I was raised paycheck to paycheck. [Lecture me] about } \\
\text { student loans? I owed over } \$ 100,000 \text { just four years ago." }\end{array}$ \\
\hline & $\begin{array}{c}\text { Governor } \\
\text { Chris Christie }\end{array}$ & $\begin{array}{l}\text { Financial } \\
\text { Management } \\
\text { competency }\end{array}$ & $\begin{array}{l}\text { Rational persuasion, } \\
\text { inspirational appeals } \\
(14: 14-15: 55)\end{array}$ & $\begin{array}{l}\text { "If you think it's bad now, in eight years before I became governor, } \\
\text { [state] taxes and fees were raised } 115 \text { times." }\end{array}$ \\
\hline \multirow{6}{*}{$\begin{array}{l}\text { Gender } \\
\text { Perceptions \& } \\
\text { Minority } \\
\text { Outreach }\end{array}$} & Donald Trump & $\begin{array}{l}\text { Comments about } \\
\text { women }\end{array}$ & $\begin{array}{l}\text { Rational persuasion, } \\
\text { inspirational appeals, } \\
\text { personal appeals, } \\
\text { exchange, } \\
\text { ingratiation }\end{array}$ & $\begin{array}{l}\text { "...big problem this country has is being politically correct. I've been } \\
\text { challenged by so many people, and I don't frankly have time for total } \\
\text { political correctness. And to be honest with you, this country doesn't } \\
\text { have time either. This country is in big trouble." }\end{array}$ \\
\hline & & & $(10: 33-12: 43)$ & “And frankly, what I say, and oftentimes it's fun, it's kidding. We \\
\hline & & & & have a good time. What I say is what I say. And honestly Megyn, if \\
\hline & & & & you don’t like it, I'm sorry. I’ve been very nice to you, although I \\
\hline & & & & $\begin{array}{l}\text { could probably maybe not be, based on the way you have treated } \\
\text { me... I wouldn't do that." }\end{array}$ \\
\hline & Ted Cruz & $\begin{array}{l}\text { Divisiveness: } \\
\text { minority } \\
\text { population } \\
\text { outreach }\end{array}$ & $\begin{array}{l}\text { Personal appeals, } \\
\text { inspirational appeals }\end{array}$ & $\begin{array}{l}\text { '... the American people are looking for someone to speak the truth. If } \\
\text { you're looking for someone...to agree with career } \\
\text { politicians...lobbyists and special interests, then I ain't your guy." }\end{array}$ \\
\hline \multirow[b]{2}{*}{ Social Issues } & $\begin{array}{l}\text { Governor } \\
\text { Walker }\end{array}$ & Pro-life Platform & $\begin{array}{l}\text { Inspirational appeals, } \\
\text { personal appeals, } \\
\text { rational persuasion } \\
\quad(16: 01-17: 01)\end{array}$ & $\begin{array}{l}\text { "I believe that is an unborn child ... in need of protection, and I've said } \\
\text { many a time that unborn child can be protected, and there are many } \\
\text { other alternatives[to protect mothers]...consistently proven." }\end{array}$ \\
\hline & $\begin{array}{l}\text { Governor } \\
\text { Huckabee }\end{array}$ & $\begin{array}{l}\text { Constitutional } \\
\text { amendment } \\
\text { banning same-sex } \\
\text { marriage and } \\
\text { abortion }\end{array}$ & $\begin{array}{l}\text { Inspirational appeals, } \\
\text { personal appeals; } \\
\text { legitimization; } \\
\text { rational persuasion } \\
\quad(17: 03-18: 39)\end{array}$ & $\begin{array}{l}\text {...next president ought to invoke Fifth and Fourteenth Amendments to } \\
\text { the constitution now [we know] baby inside the mother's womb is a } \\
\text { person at ... conception.... Supreme Court is not the supreme being, } \\
\text { and we [need to] change the policy to be pro-life and protect children } \\
\text { instead of rip up their body parts and sell them like ... [car] parts" }\end{array}$ \\
\hline
\end{tabular}


Table 3.

First 2016 Presidential Trump-Clinton Debate Influencing Tactics

\begin{tabular}{|c|c|c|}
\hline Topic & Influencing Tactic & Examples (location) \\
\hline Jobs & $\begin{array}{l}\text { Rational persuasion; } \\
\text { inspirational appeals. }\end{array}$ & $\begin{array}{c}\text { Trump: "Our jobs are fleeing [U.S.] to Mexico... China devaluing their currency, and } \\
\text { there's nobody in [government fighting] them. And we [can win]. ...they're using our } \\
\text { country as piggy bank to rebuild China, and many other countries [doing same; big } \\
\text { companies leaving U.S.]" (5:00-5:55) }\end{array}$ \\
\hline Race & $\begin{array}{l}\text { Rational persuasion; } \\
\text { inspirational appeals }\end{array}$ & $\begin{array}{l}\text { Clinton: "[Trump] started his political activity based on... racist lie that our first black } \\
\text { president was not American citizen... [Trump began] in } 1973 \text { being sued by Justice } \\
\text { Department for racial discrimination [not renting to African Americans]." } \\
\text { Trump: "[Clinton] treated [Obama] with terrible disrespect...You were after } \\
\text { him... sent out pictures of him in a certain garb..." "yes, when I was very } \\
\text { young... along with many other companies... were sued. We settled... with no } \\
\text { admission of guilt...In Florida... opened a club [receiving positive support]. No } \\
\text { discrimination against African-Americans, against Muslims, against anybody" }\end{array}$ \\
\hline
\end{tabular}
Security Rational persuasion; inspirational appeals
Clinton: "[Trump has] let loose cyber attackers to hack into government files...need to make it very clear-whether it's Russia, China, Iran, or anybody else... we will defend [this country's] citizens...I was shocked when Donald publicly invited Putin to hack into Americans."
Trump: "I was endorsed by ICE...never endorsed anybody before on immigration [and] endorsed by 16,500 Border Patrol agents... I'll take the admirals
and...generals... over political hacks that ... have led our country so brilliantly over the last 10 years...look at the mess..."


In extending the inaugural speech discussion (Table 4), students can research facts, commitment to promises (e.g., executive orders), and rise of conservative and liberal student activism following the election.

Table 4. 2017 Presidential Inauguration Speech Influencing Tactics Examples

\section{INFLUENCING TACTIC EXAMPLES (LOCATION)}

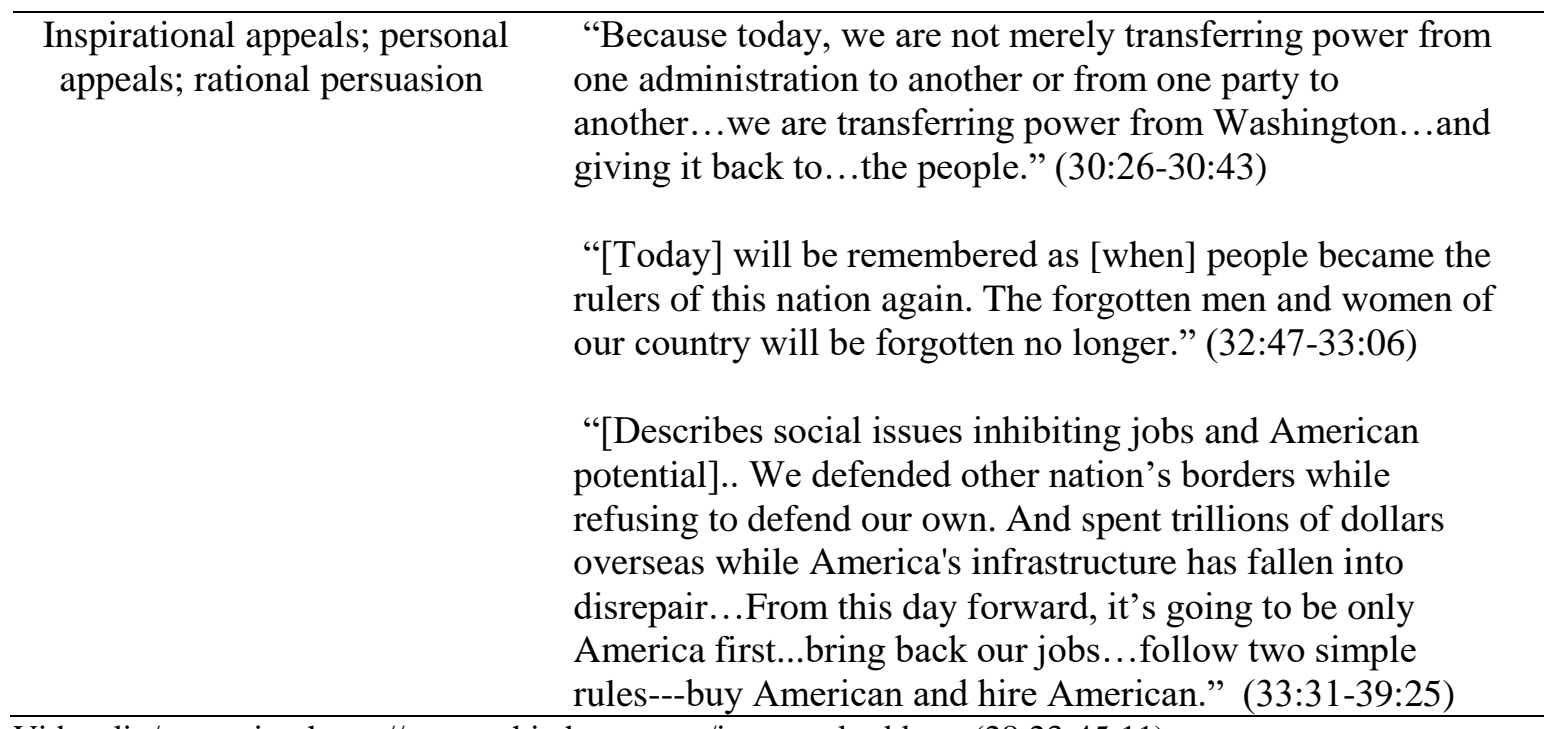

Videoclip/transcript: https://www.whitehouse.gov/inaugural-address (28:23-45:11)

Step 3. Opposite Perspective-Taking (Small groups; 15 mins). Class returns to small groups. Small groups consider two questions: (a) have your answers changed and (b) how have candidates' performances impacted social movements (e.g., free speech; activism). Small groups reflect on another group(s) contrary arguments (e.g., situations where they thought a leader used influencing tactics effectively, and another group disagreed). Role debate invites students to consider alternative perspectives without feeling forced (Donovan \& Towsend, 2016). Groups add answers to the board.

Step 4. Analyze Classmates' Influencing Tactics (Large Class; 20 mins). Students discuss how power and influence appeared in the class. Did groups change their answers? Students share examples of how influencing tactics were used to persuade students to change opinions.

Step 5. Who has Power? (Large Class; 20 mins). Using debates to stimulate discussion, instructors share what political analysts, those with expert power, predicted about winning strategies, and ask students to reflect on why (see Table 5). Students will become more engaged when realizing political analyst experts disagreed, motivating practical discussion about who determines who has power. For example, Trump's standing in the election rose after the 2015 Republican Primary debate according to the Huffington Post (2016) that tracked 235 polls from 35 pollsters. Yet, interestingly, CNN analysts (Aug 7, 2015) disagreed as only one analyst 
projected Trump as winner: a) David Gergen, senior political analyst - John Kasich and Carly Fiorina; b) Dan Pheiffer, former President Obama advisor- Marco Rubio; Tara Setmayer, political commentator -Marco Rubio; c) Mel Robins, legal analyst - Donald Trump; and, d) William Howell, political science professor - Marco Rubio. 
Table 5.

Instructor Supplemental Information: Experts' Opinions

\begin{tabular}{|c|c|c|}
\hline $\begin{array}{l}\text { RELATIONSHIP TO } \\
\text { POWER/INFLUENCE }\end{array}$ & TOPIC & DESCRIPTION \\
\hline $\begin{array}{l}\text { EXPERT POWER } \\
\text { ILLUSTRATIONS }\end{array}$ & $\begin{array}{c}\text { Expert } \\
\text { analysis } \\
\text { candidate } \\
\text { performances: } \\
\text { who won? } \\
\text { (2-5min } \\
\text { videoclips) }\end{array}$ & $\begin{array}{ll}\text { - Post-Debate Analysis: Who won first Republican Primary Debate? } \\
\circ & \text { Fox News Insider (2015) } \\
\circ & \text { Henderson, C. (2015) } \\
\circ & \text { CNN (2015) } \\
\circ & \text { Huffington Post (2015) } \\
\text { - “Can Trump Get Back on Track?” WGBH News (2016, August 8) } \\
\circ \quad \text { Panelists: Rep. Geoff Diehl, Trump Massachusetts Campaign Co- } \\
\text { Chair; Jesse Mermell, former communications director for Governor } \\
\text { Deval Patrick and Clinton supporter; Dr. Tina Opie, Associate } \\
\text { Professor, Babson College } \\
\circ \quad \text { How Clinton and Trump influence change -shaping public perception } \\
\text { in speeches (e.g., Trump responding to parents of Muslim American } \\
\text { soldier killed in action; Clinton responding to email allegations) }\end{array}$ \\
\hline $\begin{array}{l}\text { PUBLIC OPINION } \\
\text { POLLS: PROGRESS } \\
\text { IN CHALLENGING } \\
\text { STATUS QUO }\end{array}$ & $\begin{array}{c}\text { Voters' } \\
\text { perceptions } \\
\text { pre-Trump's } \\
\text { announcement } \\
\text { and } \\
\text { surrounding } \\
\text { first } \\
\text { Republican } \\
\text { Debate }\end{array}$ & 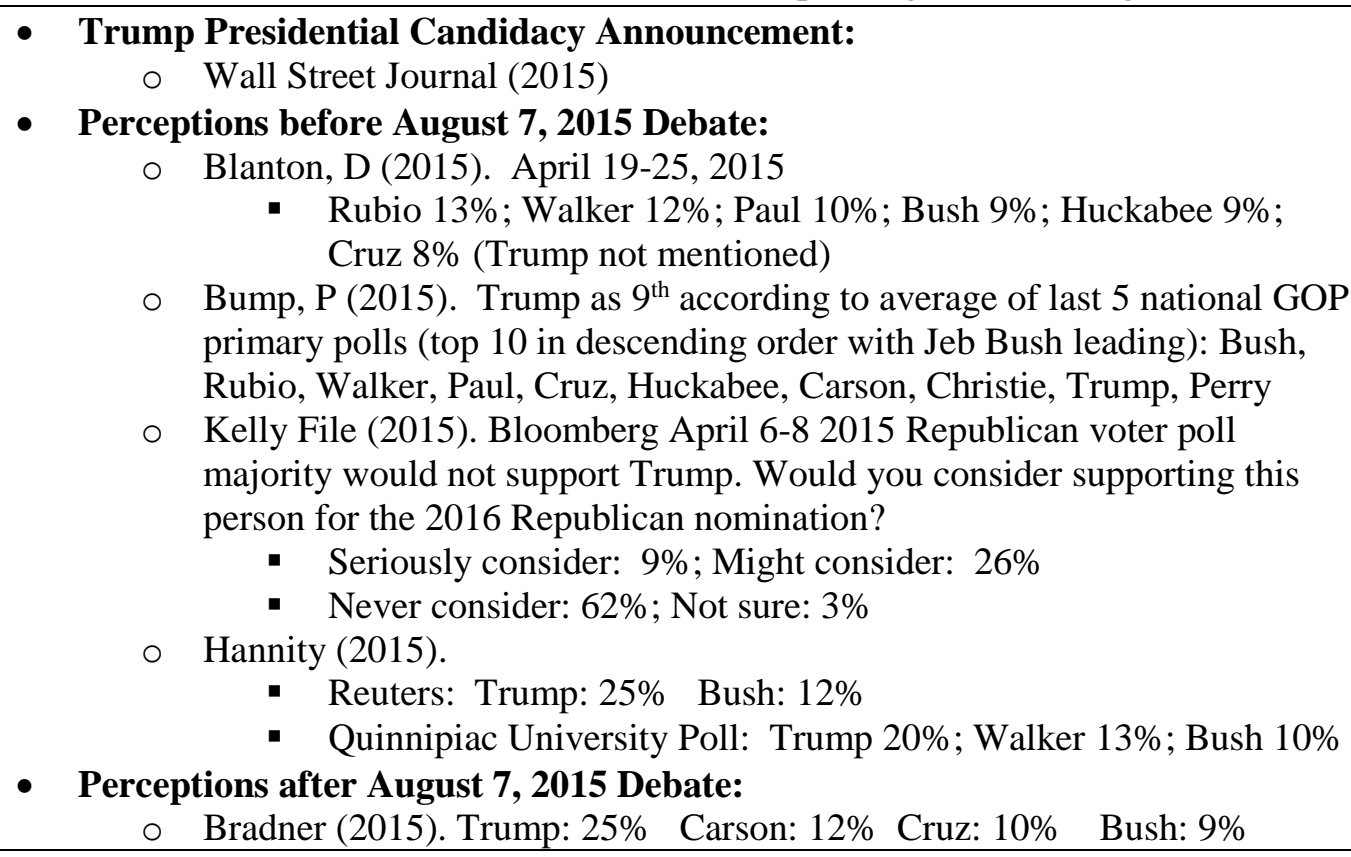 \\
\hline
\end{tabular}


Step 6. Explore Power, Social identity, and Privilege. Discuss how social identity impacts the use and perception of power and influence. Social identity is influenced by individual self-awareness of membership in specific social groups (Tajfel \& Turner, 1985). Power inequities based on race and ethnicity influence interpersonal interactions (Foldy, Rivard, $\&$ Buckley, 2008) because power provides White leaders more advantages than Black leaders in different organizational conditions (Alderfer, Alderfer, Tucker \& Tucker, 1980; Alderfer \& Smith, 1982). Challenge students to learn how social identity and privilege relate to power and influence. For example, power can be influenced by and influence gendered perceptions, as illustrated by President Trump and Ms. Kelley's interaction (see Table 2). Senator Cruz's campaign mobilized disengaged white voters and evangelical Christians (Draper, 2016). How do power and influencing tactics frame perceptions of diverse groups positively and negatively? What are implications for reducing systemic bias or oppression? Does power enable or limit diverse populations in leadership?

Media behavior illustrates power and influence. Students can learn how media, as power coalitions, impact power inequities. Gender stereotypes impact perceptions and behavior (Sandberg, 2013). For example, Trump criticized Ms. Kelly for her question about women (see Table 2). In using their own power and privilege, how did Ms. Kelly and Mr. Trump influence how the power of women is perceived? Discuss how media analyzed President Trump's power to influence public perception of diverse groups, following comments about a Muslim American soldier killed in action (Burns, Haberman, \& Parker, 2016; WGBH News, 2016).

Step 7. Practical application. Students reflect on what they learned and practical implications challenging norms. Instructors can provide visual examples of how this election subsequently motivated student activism, specifically how college students have used power and influencing tactics to challenge the status quo: conservative students suing Berkley (Fox News Insider, 2017) or college students' participation in the 2017 Women's March D.C. (Tulp, 2017). Students have realized they have more power than they thought.

Facilitator Lessons Learned. For active engagement, students should know the theory, election context, and have an independent opportunity to develop their opinion about questions with different answers. After explaining how effective leaders stand behind their opinions and actively share them, I found students listened more openly to classmates' ideas, asking them questions.

Values influence effectiveness perceptions. Debates are designed to raise contrasting views on questions; therefore, no official winner exists. Rather, individual perceptions regarding who won is impacted differently by people's values. Values determine attitudes, which determine intention, and then behavior (Ajzen, 1991). Thus, evaluating influencing tactics presents opportunities to consider how values strengthen the impact of influencing tactics positively, and negatively.

Individual voice vs. peer pressure. This exercise challenges students to take a stand and voice independent opinions prior to knowing their peers'; thus, accountability measures are necessary. Prior to class discussion, students submit original arguments in written form (e.g., essay; online discussion board). Because peer pressure silences students, I do not ask political affiliation. During my first experience, I asked them to 
share this if they wanted, and found they reiterated party views, but could not articulate their own arguments. In contrast, the discussion became more alive with divergent views, and international students felt included.

Multicultural perspectives. Classroom exercises that integrate social issues (e.g., André, 2016; White \& Sheehan, 2016) explore the multidimensional impact of leaders' decisions (Schmidt-Wilk \& Lovelace, 2016). Considering leadership perceptions differ across national cultures (Adler, 1997; Alves, Lovelace, Manz, Matsypura, Toyasaki, \& $\mathrm{Ke}, 2006$ ), I found international students were eager to participate, sharing how the U.S. presidential election impacted them and their families.

\section{Conclusion}

Overall, this exercise motivated students' desire to talk and learn from each other about what course theoretical content, particularly power and influence, means in their lives, and for their leadership goals. Most importantly, they discovered they have the power to make a difference in life.

\section{Acknowledgements}

The author would like to thank George Lebrón for his careful feedback and comments on earlier versions of this manuscript. 


\section{References}

Adler, N.J. (1997). Global leadership: women leaders. Management International Review, 37(1), 171-96.

Alderfer, C. P., \& Smith, K. K. (1982). Studying intergroup relations embedded in organizations. Administrative Science Quarterly, 27, 35-65. doi:10.2307/2392545

Alderfer, C. P., Alderfer, C. J., Tucker, L., \& Tucker, R. (1980). Diagnosing race relations in management. Journal of Applied Behavioral Science, 16, 135-166. doi:

$10.1177 / 002188638001600202$

Alves, J.C., Lovelace, K.J., Manz, C.C., Matsypura, D., Toyasaki, F., \& Ke, K. (2006). A crosscultural perspective of self-leadership. Journal of Managerial Psychology, 21(4), 338359. doi: 10.1108/02683940610663123

Ajzen, I. (1991). The theory of planned behavior. Organizational behavior and human decision processes, 50(2), 179-211.doi: 10.1016/0749-5978(91)90020-T

André, R. (2016). Who should define the "social" in "social enterprise": Elected governments or partnered corporations? Management Teaching Review, 1(3), 186-197. doi: 10.1177/ 2379298116653227

Barrone, M. (2015, September 22). Are America's familiar political alignments suddenly changing? National Review. Retrieved from http://www.nationalreview.com/article/424398/are-americas-familiar-politicalalignments-suddenly-changing-michael-barone

Blake, A. (2016, September 26). The first Trump-Clinton presidential debate transcript, annotated. The Washington Post. Retrieved from https://www.washingtonpost.com/news/the-fix/wp/2016/09/26/the-first-trump-clintonpresidential-debate-transcript-annotated/?utm_term $=.61 \mathrm{~b} 377 \mathrm{eaa} 1 \mathrm{f6}$

Blanton, D. (2015, April 24). Fox News Poll: Rubio jumps to head of 2016 GOP pack, Clinton honesty questioned. Fox News. Retrieved from http://www.foxnews.com/politics/2015/04/23/fox-news-poll-rubio-jumps-to-head-2016gop-pack-clinton-honesty-questioned.html

Bongila, J. (2011). Shaping influences on the leadership of Genghis Khan, George Washington, and Nelson Mandela: Applications for educators. Journal of Leadership Education, 10(2): 138-154. doi: 10.12806/V10/I2/RF7

Bradner, E. (2015, August 17). Poll. GOP establishment candidates falling. CNN. Retrieved from http://www.cnn.com/2015/08/16/politics/gop-poll-jeb-bush-scott-walker-marco-rubiodrop-2016/ 
Bryant, N. (2016, May 5). US election: Will normal rules ultimately apply? BBC News.

Retrieved from http://www.bbc.com/news/election-us-2016-36203799

Bump, P. (2015, May 20). Fox News laid out its debate rules. Here's who would make the cut today. Washington Post. Retrieved from https://www.washingtonpost.com/news/thefix/wp/2015/05/20/fox-news-lays-out-who-can-be-in-its-debate-doing-little-to-actuallyanswer-the-question/

Burke, L. A., \& Moore, J. E. (2003). A perennial dilemma in OB education: Engaging the traditional student. Academy of Management Learning \& Education, 2(1), 37-52. doi: 10.5465/AMLE.2003.9324016

Burns, A., Haberman, M., \& Parker, A. (2016, July 31). Donald Trump's confrontation with Muslim soldier's parents emerges as unexpected flash point. New York Times. Retrieved from http://www.nytimes.com/2016/08/01/us/politics/khizr-khan-ghazala-donald-trump$\underline{\text { muslim-soldier.html }}$

Burns, A., \& Martin, J. (2016, July 19). Donald Trump claims nomination, with discord clear but family cheering. New York Times. Retrieved from http://www.nytimes.com/2016/07/20/us/politics/donald-trump-rnc.html

Chan, J., Fu, K., Schunn, C., Cagan, J., Wood, K., \& Kotovsky, K. (2011). On the benefits and pitfalls of analogies for innovative design: Ideation performance based on analogical distance, commonness, and modality of examples. Journal of Mechanical Design. doi:10.1115/1.4004396.

Clegg, S. (1989). Frameworks of power. London: Sage.

CNN. (2015). CNN opinion: So who won the Republican debate? CNN. Retrieved from http://www.cnn.com/2015/08/07/opinions/opinion-gop-debate-roundup/

Deschamps, J. (1982). Social identity and relations of power between groups. In H. Tajfel (Ed.), Social identity and intergroup relations (pp. 85-98). New York: Cambridge University Press.

Diaz, D. (2015). The 2016 rhetoric is getting out of control. CNN Politics. Retrieved from http://www.cnn.com/2015/08/28/politics/donald-trump-hillary-clinton-2016-electionpolitical-hits/

Diesing, P. (1962). Reason in society: Five types of decisions and their social conditions. Greenwood Press.

DiMaggio, P.J., \& Powell, W.W. (1983). The iron cage revisited: Institutional isomorphism and collective rationality in organizational fields. American Sociological Review, 48, 147 160. doi: $10.2307 / 2095101$ 
Donovan, P., \& Townsend, J. (2016). The role of debate in moving minds. Management Teaching Review, 1(1), 19-25. doi: 10.1177/2379298115621702

Draper, R. (2016, January 26). Ted Cruz's evangelical gamble. New York Times. Retrieved from http://www.nytimes.com/2016/01/31/magazine/ted-cruzs-evangelical-gamble.html?_r=0

Edmondson, A.C., Roberto, M.A., \& Watkins, M.D. (2003). A dynamic model of top management team effectiveness: Managing unstructured task streams. The Leadership Quarterly, 14(3), 297-325. doi: 10.1016/S1048-9843(03)00021-3

File, T. (2014). Young adult voting: An analysis of presidential elections, 1964-2012. U.S. Census. Retrieved from https://www.census.gov/prod/2014pubs/p20-573.pdf

Foldy, E.G., Rivard, P., \& Buckley, T. (2009). Power, safety, and learning in racially diverse groups. Academy of Management Learning and Education, 1(8): 25-41. doi: 10.5465/AMLE.2009.37012177

Fox News. (2015, August 7). Fox News primetime presidential debate. Fox News. Retrieved from http://video.foxnews.com/v/4406746003001/watch-a-replay-of-fox-news-primetime-presidential-debate/?\#sp=show-clips

Fox News Insider. (2015). Who won the primetime GOP debate? Analysists weigh in. Fox News Insider. Retrieved from http://insider.foxnews.com/2015/08/06/who-won-gop-primetimedebate-analysts-weigh

Fox News Insider (2017, April 26). Conservative students suing Berkeley over Coulter speech. Fox News Insider. Retrieved from http://insider.foxnews.com/2017/04/26/conservativestudents-suing-berkeley-over-ann-coulter-speech

French, J. R. P., Jr., \& Raven, B. H. (1959). The bases of social power. In D. Cartwright (Ed.), Studies in social power (pp. 150-167). Ann Arbor, MI: Institute for Social Research.

Galinsky, A. D., Rucker, D. D., \& Magee, J. C. (2015). Power: Past findings, present considerations, and future directions. In J. A. Simpson \& J. F. Dovidio (Associate Eds.), M. Mikulincer \& P. R. Shaver (Eds.), APA Handbook of Personality and Social Psychology. Vol. 3: Interpersonal relations (pp. 421-460). Washington, DC: American Psychological Association. doi: 10.1037/14344-016

Goertzen, B. (2007). Social security: A pending crisis. A leadership and politics debate. Journal of Leadership Education, 6(1), 226-236. doi: 10.12806/V6/I1/AB1

Hannity. (2015, July 31). What is driving up Donald Trump's Numbers? Fox News. Retrieved from http://www.foxnews.com/transcript/2015/07/31/what-is-driving-up-donald-trumpnumbers/ 
Hardy, C., \& Clegg, S.R. (1996). Some dare call it power. In S.R. Clegg, C. Hardy, \& W.R Nord (Eds.), Handbook of organization studies (pp.622-641). London: Sage.

Henderson, C. (2015). Winners \& losers in $1^{\text {st }}$ GOP debate. Fox News. Retrieved from http://www.foxnews.com/us/2015/08/07/winners-losers-in-1st-gop-debate/

Huffington Post. (2016). 2016 National Republican Primary Poll Results. Retrieved from http://elections.huffingtonpost.com/pollster/2016-national-gop-primary

Kelly File. (2015, May 21). Donald Trump: I want to make the country great again. Fox News. Retrieved from http://www.foxnews.com/transcript/2015/05/21/donald-trump-want-tomake-country-great-again/

Keltner, D., Gruenfeld, D. H., \& Anderson, C. (2003). Power, approach, and inhibition. Psychological Review, 110(2), 265 -284. doi: 10.1037/0033-295X.110.2.265

Kessler, G. (2015, August 7). Fact checking the first GOP presidential debates. Washington Post. Retrieved from https://www.washingtonpost.com/news/fact-checker/wp/2015/08/07/factchecking-the-first-gop-presidential-debates/

Kipnis, D., Schmidt, S. M., Swaffin-Smith, C., \& Wilkinson, I. (1984). Patterns of managerial influence: Shotgun managers, tacticians, and bystanders. Organizational Dynamics, 12(3), 58-67. doi: 10.1016/0090-2616(84)90025-1

Kipnis, D., Schmidt, S. M., \& Wilkinson, I. (1980). Intraorganizational influence tactics: Explorations in getting one's way. Journal of Applied Psychology, 65(4), 440-452. doi: 10.1037//0021-9010.65.4.440

Koslowsky, M., Schwarzwald, J., \& Ashuri, S. (2001). On the relationship between subordinates' compliance to power sources and organisational attitudes. Applied Psychology, 50(3), 455-476. doi: 10.1111/1464-0597.00067

Kurtzleben, D. (2017, April 28). 100 days in, women's march still inspires. But can enthusiasm hold? National Public Radio. Retrieved from http://www.npr.org/2017/04/28/525764938/100-days-in-womens-march-still-inspiresbut-can-the-enthusiasm-hold

Lee, J., \& Lim, Y. S. (2016). Gendered campaign tweets: The cases of Hillary Clinton and Donald Trump. Public Relations Review, 42(5), 849-855. doi: 10.1016/j.pubrev.2016.07.004

Lussier, R. N., \& Achua, C. F. (2013). Leadership: Theory, application, and skill development (5th ed.). Mason, OH: South-Western Cengage Learning. 
Magee, J.C., \& Galinsky, A.D. (2008). Social hierarchy: The self-reinforcing nature of power and status. The Academy of Management Annals, 2(1), 351-398. doi:

$10.1080 / 19416520802211628$

Martin, J. (2016, May 25). As Donald Trump pushes conspiracy theories, right-wing media gets its wish. New York Times. Retrieved from http://www.nytimes.com/2016/05/26/us/politics/donald-trump-presidentialrace.html?_r=1

Mitchell, D. (2015, May 4). Here's why Carly Fiorina is such a controversial figure. Time. Retrieved from http://time.com/3845767/carly-fiorina-hp/

New York Times. (2016, September 27). Full video: First presidential debate. New York Times. Retrieved from https://www.nytimes.com/video/us/politics/100000004673000/full-videofirst-presidential-debate.html

Niemi, R.G., \& Hanmer, M.J. (2010). Voter turnout among college students: New data and a rethinking of traditional theories. Social Science Quarterly, 91(2), 301-323. doi:

10.1111/j.1540-6237.2010.00694.x

Pfeffer, J. 1981. Power in organizations. Marshfield, MA: Pittman.

Pierro, A., Cicero, L., \& Raven, B. H. (2008). Motivated compliance with bases of social power. Journal of Applied Social Psychology, 38(7), 1921-1944. doi: 10.1111/j.15591816.2008.00374.x

Pierro, A., Kruglanski, A. W., \& Raven, B. H. (2012). Motivational underpinnings of social influence in work settings: Bases of social power and the need for cognitive closure. European Journal of Social Psychology, 42(1), 41-52. doi: 10.1002/ejsp.836

Pierro, A., Raven, B. H., Amato, C., \& Bélanger, J. J. (2013). Bases of social power, leadership styles, and organizational commitment. International Journal of Psychology, 48(6), 1122-1134. doi: 10.1080/00207594.2012.733398

Przybyla, H.M., \& Schouten, F. (2017, January 21). At 2.6 million strong, women's marches crush expectations. USA Today. Retrieved from https://www.usatoday.com/story/news/politics/2017/01/21/womens-march-aims-startmovement-trump-inauguration/96864158/

Raven, B. H. (1965). Social influence and power. In I.D. Steiner \& M. Fishbein (Eds.), Current studies in social psychology, (pp 371-382). New York: Holt, Rinehart, Winston.

Raven, B. H. (1992). A power/interaction model of interpersonal influence: French and Raven thirty years later. Journal of Social Behavior and Personality, 7, 217-244. 
Raven, B. H. (1993). The bases of power: Origins and recent developments. Journal of Social Issues, 49(4), 227-251. doi: 10.1111/j.1540-4560.1993.tb01191.x

Raven, B. H. (1999). Influence, power, religion, and the mechanisms of social control. Journal of Social Issues, 55(1), 161-186. doi: 10.1111/0022-4537.00111

Raven, B. H. (2008). The bases of power and the power/interaction model of interpersonal influence. Analyses of Social Issues and Public Policy, 8(1), 1-22. doi: 10.1111/j.15302415.2008.00159.x

Raven, B. H., Schwarzwald, J., \& Koslowsky, M. (1998). Conceptualizing and measuring a power/interaction model of interpersonal influence1. Journal of Applied Social Psychology, 28(4), 307-332. doi: 10.1111/j.1559-1816.1998.tb01708.x

Sandberg, S. (2013). Lean in: Women, work, and the will to lead. New York, NY: Alfred A. Knopf.

Schmidt-Wilk, J., \& Lovelace, K.J. (2016). Something for everyone. Management Teaching Review, 1(3), 140-141. doi: 10.1177/2379298116659837

Schriesheim, C. A., \& Hinkin, T. R. (1990). Influence tactics used by subordinates: A theoretical and empirical analysis and refinement of the Kipnis, Schmidt, and Wilkinson subscales. Journal of Applied Psychology, 75(3), 246 - 257. doi: 10.1037//0021-9010.75.3.246

Schwarzwald, J., Koslowsky, M., \& Agassi, V. (2001). Captain's leadership type and police officers' compliance to power bases. European Journal of Work and Organizational Psychology, 10(3), 273-290. doi: 10.1080/13594320143000672

Simpson, J. A., Farrell, A. K., Orina, M. M., \& Rothman, A. J. (2015). Power and social influence in relationships. In M. Mikulincer \& P. Shaver (Eds.), Interpersonal Relations: Vol. 3, APA handbook of personality and social psychology (pp.393-420). American Psychological Association. doi: 10.1037/14344-015

St. John, P. (2017, April 24). Republican students sue to allow Ann Coulter's speech this week at UC Berkeley. Los Angeles Times. Retrieved from http://www.latimes.com/local/education/la-me-ann-coulter-20170424-story.html

Sturm, R. E., \& Antonakis, J. (2015). Interpersonal power: A review, critique, and research agenda. Journal of Management, 41(1), 136-163. doi: 10.1177/0149206314555769

Tajfel, H., \& Turner, J.C. (1985). The social identity theory of intergroup behavior. In S. Worchel \& W.G. Austin (Eds.), Psychology of intergroup relations (2 ${ }^{\text {nd }}$ ed., pp. 7-24). Chicago: Nelson-Hall. 
Taranto, J. (2016, Nov 15). Trump vs. political correctness; some early encouraging signs. Wall Street Journal (Online) Retrieved from https://www.wsj.com/articles/trump-vs-politicalcorrectness-1479233123

Time. (2015, August 11, 2015). Transcript: Read the full text of the primetime Republican Debate. Time. Retrieved from http://time.com/3988276/republican-debate-primetime$\underline{\text { transcript-full-text/ }}$

Tufts University. Jonathan M. Tisch College of Civic Life. The Center for information and Research on Civic Learning and Engagement (CIRCLE). (2016, November 9). An estimated 24 million young people voted in 2016 election. Retrieved from http://civicyouth.org/an-estimated-24-million-young-people-vote-in-2016-election/

Tulp, S. (2017, January 25). Here's what the Women's March D.C. looked like to college women. USA Today College. Retrieved from http://college.usatoday.com/2017/01/25/womens-march-on-washington/

Wall Street Journal. (2015, June 16). Donald Trump announces presidential campaign. Wall Street Journal. Retrieved from http://www.wsj.com/video/donald-trump-announcespresidential-campaign/FC815E51-F818-4A4C-9711-05F18E8918BE.html

WGBH News (2016, August 8). Can Trump get back on track? WGBH News. Retrieved from http://news.wgbh.org/2016/08/08/local-news/watch-can-trump-get-back-track

White, S., \& Sheehan, G. (2016). The impact of reframing on decision making: An exercise in community development. Management Teaching Review, 1(3), 176-185. doi: $10.1177 / 2379298116651299$

Wilz, K. (2016). Bernie Bros and Woman Cards: Rhetorics of Sexism, Misogyny, and Constructed Masculinity in the 2016 Election. Women's Studies in Communication, 39(4), 357-360. doi: 10.1080/07491409.2016.1227178

\section{Author Biography}

Dr. Mariana Lebrón is an assistant professor of management in the Department of Management, College of Business and Economics, at Towson University. She teaches and consults about organizational leadership, change, and behavior. Her research considers how power and influence impact high-performing diverse teams. She is a motivational speaker for impacting positive societal change. Email: mlebron@towson.edu 